\title{
TEATRO POLÍTICO NO BRASIL
}

\author{
Iná Camargo COSTA ${ }^{1}$
}

- RESUMO: Trata-se de uma caracterização do teatro político no Brasil, a partir da história do teatro político desde a Antigüidade, passando pelo século XIX, pelo teatro americano e chegando ao teatro brasileiro dos anos 60 .

- PALAVRAS-CHAVE: Teatro; política; teatro brasileiro.

Como tratei deste tema por extenso em $A$ hora do teatro épico no Brasil (1996) e agora estou trabalhando com o teatro que se fez por aqui nos anos 40 e 50, vou apresentar uma digressão do que podemos chamar as razões políticas dos inimigos do teatro político no mundo inteiro.

Por isso mesmo, é bom começar esclarecendo de saída que, para a corrente de pensadores com a qual me identifico, o teatro político desde sempre é muito mais político quando se declara apolítico ou contra o teatro político. Começando por nossa "matriz" teórica, Aristóteles, de quem costumamos ler só a Arte poética, passando pela segunda metade do século XIX na França - momento emblemático de um teatro político que se empenhava em combater a ferro e fogo o teatro político que nos interessa -, até chegar aos tempos da guerra fria, logo depois da Segunda Guerra Mundial, quando foram retomados os valores críticos do período acima. Os militantes do teatro político no Brasil tiveram que enfrentarnem sempre com muito sucesso - as convicções de tipo esteticista consolidadas então.

1 Departamento de Teoria Literária e Literatura Comparada - Faculdade de Filosofia, Letras e Ciências Humanas - Universidade de São Paulo - USP - 05508-900 - SP - Brasil. 


\section{Política teatral em Atenas}

Embora a leitura da Poética de Aristóteles seja indispensável para a compreensão da tragédia grega, ${ }^{2}$ estou convencida de que só ela não é suficiente. Além da Arte retórica, os interessados no teatro grego deveriam ler também A constituição de Atenas. Aqui Aristóteles dá importância ao teatro em sua dimensão política. A tal ponto reconhecida pelos atenienses que os legisladores definiram como responsabilidade da administração não só apenas garantir as realizações dos festivais e concursos, como ainda assegurar os salários dos artistas (cantores, músicos) e técnicos, tudo em nome do Conselho de Atenas.

Quanto à relevância política dos assuntos tratados nas tragédias, basta lembrar que Eurípedes caiu em desgraça quando escreveu e apresentou As troianas - um dos mais valiosos libelos pacifistas da história do teatro ocidental. Foi um pronunciamento do poeta contra os planos gregos de guerra então em andamento.

\section{Renascimento político do teatro}

Como se sabe, com o virtual desaparecimento das cidades na Idade Média, o teatro foi recolhido pelas igrejas e mosteiros e recebeu a tarefa, sempre política, de ilustrar as passagens mais relevantes da Bíblia, com preferência centrada no Novo Testamento (os católicos têm muita dificuldade de enfrentar o Antigo Testamento,talvez porque prefiram evitar a história comum que partilham com os judeus). Sabe-se também que esse mesmo teatro, tratando dos assuntos definidos pela própria Igreja, acabou sendo expulso do recinto sagrado porque os artistas, por uma espécie de impulso irrefreável, começaram a introduzir nas peças cenas de diálogos consideradas grotescas e obscenas pelas autoridades.

Expulso, o teatro ganhou as ruas (as cidades começaram a se desenvolver) e, mesmo tratando dos temas bíblicos (mas agora com o direito de incluir as histórias do Antigo Testamento, desde o Gênesis), ganhou liberdade de neles incluir os temas profanos (grotescos, obscenos etc.) da vida de todos. Em Mistero Buffo, Dario Fo explica que por isso o teatro se tornou desde então o jornal falado do povo.

2 A comédia ficou de fora e não acredito que tenha sido escrita: o filósofo, muito sério, não iria se "rebaixar" a tratar dos gêneros que tinham "homens inferiores" como personagens. 


\section{A política do esteticismo}

O teatro convencional, de palco italiano, em prosa etc., que conhecemos, de novo confinamento. Mas esse se deve ao aparecimento de nova religião - a do mercado. A construção de edifícios próprios para os espetáculos, com bilheteria na porta, corresponde a transformações em mercadoria daquilo que tinha sido durante séculos uma atividade a que se dedicavam todos os habitantes de uma cidade. Não se pode ignorar, por outro lado, que a essa apropriação privada de uma prática socialcoletiva corresponderam enormes avanços de ordem técnica e estética - basta pensar nos complicadíssimos dos teatros do século XVIII.

Embora desde fins do século XVI o teatro mais relevante tenha sido transformado em mercadoria, num país como a França a burguesia só conseguiu dominá-lo do ponto de vista político, teórico e estético após a Revolução de 1789. Nos dez anos que se seguiram à queda da Bastilha, nenhum teatro na França (das revistas nas feiras à Comédie Française) se dedicou a outro assunto que não fosse a política. Não passava pela cabeça de ninguém que o teatro pudesse se interessar por qualquer outra coisa. Há até relatos de que o espetáculo acabou se transformando em assembléia mesmo: os cidadãos da platéia debatendo com os cidadãos no palco sobre os rumos da história (Gaiffe, 1910).

A cena francesa expressou de maneira quase mecânica os avanços e retrocessos da Revolução. Assim, à medida que a burguesia foi se acertando com a Igreja e com a aristocracia, o teatro foi abandonando as conquistas de 1789, até mesmo a liberdade, para tratar abertamente das questões políticas. Atalhando bastante essa história, chegaremos ao momento em que o esteticismo foi promovido a política de Estado.

$\mathrm{Na}$ França, os trabalhadores e suas reivindicações entraram em cena em 1848, quando derrubaram a Monarquia de 1830 e foram logo em seguida massacrados pelo exército e demais forças militares a serviço da ordem. Pouco tempo depois desse massacre, um golpe de Estado funda o que conhecemos como Segundo Império, devidamente explicados, golpe e forma de governo, em obra de leitura indispensável: O dezoito brumário de Luís Bonaparte.

Uma das estratégias de Luís Bonaparte, assumida com a mesma ferocidade com que executou, baniu e perseguiu seus inimigos (até mesmo Victor Hugo por ser contra a pena de morte), foi definida como "trabalho da supressão da memória". Isso impedia que os massacres promovidos desde 1848, assim como o motivo das lutas dos trabalhadores (miséria, condições de vida e trabalho etc., o de sempre), fossem mencionados em 
quaisquer circunstâncias - jornais, obras literárias e demais formas culturais. Para tanto, foi criada uma lei de censura rigorosíssima, à qual nada escapava, como não escapou o jornal de Victor Hugo, Madame Bovary, de Flaubert, As flores do mal, de Baudelaire, para ficarmos só nesses exemplos mais conhecidos. Peças originais ou adaptações de romances de Emile Zola e dos irmãos Goncirert ficaram anos e anos (em alguns casos, mais de vinte) retidas no departamento de censura.

A face propositiva desse programa consistiu em desenterrar as obras de Racine e Molière, promovidas à condição de modelos para o drama $\mathrm{e}$ para a comédia. Esse item da plataforma encontrou terreno fértil para prosperar até mesmo na universidade e na Academia, que produziram as teorias teatrais com as quais estamos nos acertando até hoje (em seguida trataremos de sugerir as razões políticas). $\mathrm{Na}$ imprensa, autorizada e financiada, prosperaram as versões popularizadas dessas convicções na forma da crítica teatral (em alguns casos, a mesma pessoa acumulava três funções: professor de literatura, acadêmico e crítico teatral).

Já nos palcos, prosperou o que se chama "teatro realista", sendo Alexandre Dumas Filho (Dama das Camélias) e Emile Augier os mais celebrados dramaturgos. Novamente, temos aqui um caso ilustrativo de dupla militância: o mesmo Emile Augier que, como artista, evitava assuntos da esfera política e, como funcionário público, trabalhava justamente como censor, se encarregava de vetar aquelas peças que não correspondiam a seus "altos padrões estéticos".

Resumindo bastante: sob a bandeira da autonomia da arte, na França, o esteticismo surgiu na segunda metade do século XIX como uma política para as artes que está nos antípodas da formulação kantiana: para Kant, a autonomia da arte é sinônimo de liberdade (para tratar de qualquer assunto) enquanto o pressuposto do esteticismo francês é a censura mais feroz.

O Segundo Império, derrotado na guerra franco-prussiana e durante a revolução conhecida como Comuna de Paris, foi devidamente massacrado pelo exército prussiano a soldo da República proclamada em Versalhes, também conhecida como Segunda República. Em vista dessa origem sangrenta, análoga à do Segundo Império, não é preciso muito para entender por que a Terceira República manteve intacta a lei de censura ao teatro elaborada pelo regime que a antecedeu. É essa a causa institucional da criação, por Artoine e amigos, do teatro livre: uma associação de teatro amador que, por isso mesmo, não estava sujeita às leis de censura, $\mathrm{e}$ por esse motivo estreou com uma peça em um ato chamada Jacques Damour, cujo protagonista é um veterano da Comuna de Paris que volta do exílio e encontra sua família destruída. 
Como já tratamos, em outro lugar, da história dos teatros livres, vamos fazer novo corte e tratar do episódio análogo ao Segundo Império nos Estados Unidos da guerra fria.

\section{A política da antipolítica norte-americana}

Embora não se tenha nenhum episódio compáravel às revoluções de 1848 ou à Comuna de Paris nos Estados Unidos, é um fato histórico que esse país teve atividades teatrais ligadas aos movimentos dos trabalhadores (socialistas, anarquistas, comunistas) desde o século XIX. Essas tradições confluíram para um grande movimento cultural nos anos 30 denominado "os anos vermelhos". ${ }^{3}$

A cultura de esquerda dos anos 30 chegou mesmo a ser hegemônica e, segundo Michael Denning (1996), até hoje o que se produz de interessante, mesmo em Hollywood, é tributário dessa experiência. Digase de passagem que o mesmo processo se observou, por exemplo, na universidade, onde notórios militantes da "arte pela arte" se converteram ao engajamento, chegando a fazer declarações publicas a favor da politização das artes e da literatura, como foi o caso de um conhecido "esteticista" chamado Kenneth Burke.

Não é possível recontruir o processo que levou a grande maioria dos envolvidos no "front cultural" ao esforço de guerra, mas o fato é que muitos comunistas e esquerdistas das mais diversas facções se tornaram funcionários públicos, trabalhando nas divisões de informação e propaganda de guerra. Não se deve esquecer de que os aliados na luta contra Hitler contavam com a União Soviética, cujo Exército Vermelho foi essencial para a derrota nazista no Leste Europeu.

Pois muito bem, acabada a guerra em 1945, Churchill, já em 1946, proclamou, em discurso proferido nos Estados Unidos, o início da guerra fria - combate ao comunismo em todas as frentes. Em 1947, o governo Trumam decretou um programa de lealdade aos Estados Unidos, determinando a demissão de comunistas que trabalhavam em qualquer instância governamental, nas escolas (da universidade ao ensino fundamental), nos meios de comunicação (rádio, televisão, cinema) e nas divisões públi-

3 The Cultural Front (London: Verso, 1996) de Michael Denning é um livro que procura dar conta de todas as atividades, nas mais diversas modalidades culturais - das histórias em quadrinhos à música de Billie Holiday, passando pelo teatro e pelo cinema. 
cas (teatro e demais atividades conexas). O codinome dessa ampla caça às bruxas é macartismo, do qual só conhecemos os episódios de perseguição a roteiristas e diretores de Hollywood, mas as sessões do Comitê de Investigações de Atividades Antiamericanas (HUAC) são apenas a ponta do iceberg. Existem estudos mais amplos sobre a devastação produzida na sociedade norte-americana por esse programa do governo Truman, criado em nome do combate à "ameaça vermelha".

A versão política no campo que nos interessa - o teatro, a crítica teatral, a história e o ensino do teatro - corresponde à ressurreição dos princípios do new criticism dos anos 20 e 30 e à reabilitação, por meio dos espetáculos da Broadway e da crítica de jornais, da "peça bem-feita" relativamente modernizada.

Por "peça bem-feita" relativamente modernizada entenda-se a receita formulada pelos franceses ainda nos anos 20 do século XX e explicitada pelo alemão Gustav Freytag nos anos 60. Essa receita, após os abalos provocados pela dramaturgia moderna - as experiências do naturalismo e as inspiradas na psicanálise - foi por assim dizer recauchutada nos manuais de dramaturgia americanos que têm por título ou subtítulo understanding drama. Eles são o equivalente dos mais bem apreciados understanding poetry e understanding prose, e as três understandings correspondem à velha e boa teoria dos gêneros literários.

Até hoje prevalece no ensaio de dramaturgia a velha receita da "peça bem-feita" reciclada pelos americanos. Por ela, fica combinado que o texto teatral não pode tratar de assuntos políticos, uma vez que esses tendem a tornar a peça muito arrastada, porque o diálogo, nesse caso, fica muito pouco ágil, uma vez que ele deixa de estar a serviço da ação dramática.

Desde fins dos anos 40, a Broadway promove dramaturgos que, consciente ou inconscientemente, aderem a essa regra, que conseguiu se impor aos longo dos anos 50. Mas já nos anos 60 esse panorama se altera significamente, episódio de que não trataremos agora.

\section{Teatro moderno para o bem do Brasil}

Os jovens que no Brasil assumiram a missão civilizatória de dotar o Brasil de um teatro moderno foram diretamente influenciados pelo processo norte-americano - por razões políticas. O Departamento de Estado promoveu um amplo programa de formação de intelectuais brasileiros que deveriam atuar no front teatral. Do Rio de Janeiro e de São Paulo 
foram enviados jovens com bolsa de estudos para os Estados Unidos (Décio de Almeida Prado inclusive). Lá eles assistiriam às peças e entrariam em contato com críticos e professores de teatro, de modo que, na volta, poderiam, com conhecimento de causa, defender a bandeira da atualização da cena brasileira por meio da dramaturgia americana. Como já tínhamos uma tradição de dependência do teatro francês, nossa cena dos anos 50 se caracterizou por uma interessante acomodação da dramaturgia francesa e americana. A crítica seguiu mais ou menos o mesmo caminho, produzindo uma reflexão mais ou menos franco-americana. ${ }^{4}$

Atalhando mais uma vez, os valores do teatro antipolítico, ainda hoje defendidos por muitos entre nós, se sedimentaram nos anos da guerra fria.

\section{O teatro político que interessa}

Como na vida real as coisas nem sempre acontecem segundo os estrategistas de Washington, nos anos 50 o teatro brasileiro deu uma guinada à esquerda que fugiu inteiramente dos planos esteticistas. Foi tudo muito rápido: em 1958, o Teatro de Arena de São Paulo encenou Eles não usam black tie, em 1960, Revolução na América do Sul e, em 1962, Vianinha e companheiros fundaram o Centro Popular de Cultura (CPC) da UNE. No CPC realizaram-se as experiêcias mais radicais de teatro que até hoje não foram devidamente analisadas, entre outros motivos, porque elas não correspondem às expectativas dos manuais franceses ou americanos com que continuamos sendo alfabetizados. Os que se consideram dessas experiências têm muito a estudar e a fazer. Primeiro, descobrir e incorporar criticamente as experiências do naturalismo. Depois, conhecer a história dos teatros livres (a verdadeira, não a escrita pelos inimigos). Em seguida, a extraordinária e riquíssima história do agit prop da Revolução soviética, sem a qual a obra de um Maiakovski fica incompreensível. O capítulo seguinte é o alemão, que culmina em Brecht, o dramaturgo e maior teórico do teatro épico. Com essas informações, ficará mais fácil enfrentar a tarefa de conhecer e dar a conhecer as experiências do teatro político no Brasil.

4 Já tratei esquematicamente do fenômeno no ensaio "A resistência da crítica no teatro épico" (1998). 
Trata-se de tarefa urgente, porque tudo indica que ele começa a reaparecer com muita vitalidade entre nós.

COSTA, I. C. Political theater in Brazil. Trans/Form/Ação (São Paulo), v.24, p.113120, 2001.

- ABSTRACT: This article consists in a characterization of Brazilian political theater, from the history of the political theater since antiquity, through the $19^{\text {th }}$ Century, the American theater to Brazilian theater of the 60 s.

- KEYWORDS: Theater; politics; Brazilian theater.

\section{Referências bibliográficas}

COSTA, I. C. A hora do teatro épico no Brasil. São Paulo: Graal,1996.

. Sinta o drama. Petrópolis: Vozes, 1998.

DENNING, M. The Cultural Front. London: Verso, 1996.

GAIFFE, F. Le drame en France au XVIIIème siècle. Paris: Armand Colin, 1910. 